\title{
Two new deepwater sea anemones (Cnidaria: Anthozoa: Actiniaria) Sicyonis heliodiscus sp.n. (Actinostolidae) and Hormathia pacifica sp.n. (Hormathiidae) from Pacific
}

\author{
N.P. Sanamyan ${ }^{1}$, K.E. Sanamyan ${ }^{1 *}$, L. Lundsten ${ }^{2}$ \\ ${ }^{1}$ Kamchatka Branch of Pacific Geographical Institute, Far-Eastern Branch of the Russian \\ Academy of Sciences, Partizanskaya 6, Petropavlovsk-Kamchatsky, 683000, Russia. \\ e-mail: actiniaria@sanamyan.com \\ * corresponding author \\ ${ }^{2}$ Monterey Bay Aquarium Research Institute, 7700 Sandholdt Road, Moss Landing, CA 95039, \\ USA. \\ e-mail: lonny@mbari.org
}

ABSTRACT: Sicyonis heliodiscus sp.n. and Hormathia pacifica sp.n. are described from the Taney Seamounts, NE Pacific. The species belonging to these two genera are known mainly from N Atlantic and Antarctic locations, and only a few species were recorded from the Pacific. Sicyonis heliodiscus sp.n. is a large species which has unusual exterior with short column hidden in live specimens under the wide oral disk and short marginal tentacles directed downward. It is a rare species, which have been observed only a few occasions during more than 25 years of research by the Monterey Bay Aquarium Research Institute. In contrast, Hormathia pacifica sp.n. is common at the Taney Seamounts. It has a common appearance for the genus and can be distinguished from other Hormathia species by a combination of features including the morphology of the body and cnidom.

How to cite this article: Sanamyan N.P., Sanamyan K.E., Lundsten L. 2015. Two new deepwater sea anemones (Cnidaria: Anthozoa: Actiniaria) Sicyonis heliodiscus sp.n. (Actinostolidae) and Hormathia pacifica sp.n. (Hormathiidae) from Pacific // Invert. Zool. Vol.12. No.2. P.131-149. doi: 10.15298/invertzool.12.2.02

KEY WORDS: Sea anemone, Actiniaria, North Pacific, Taney Seamounts, abyssal, Actinostolidae, Hormathiidae.

\section{Два новых вида глубоководных актиний (Cnidaria: Anthozoa: Actiniaria) Sicyonis heliodiscus sp.n. (Actinostolidae) и Hormathia pacifica sp.n. (Hormathiidae) из Пацифики}

\author{
Н.П. Санамян ${ }^{1}$, К.Э. Санамян ${ }^{1}$, Л. Ландстен² \\ ${ }^{1}$ Камчатский филиал Тихоокеанского института географии ДВО РАН, ул. Партизанская, \\ 6, Петропавловск-Камчатский 683000, Россия. \\ e-mail: actiniaria@sanamyan.com \\ ${ }^{2}$ Исследовательский институт Аквариума залива Монтерей,7700 Sandholdt Road, Moss \\ Landing, Калифорния, США. \\ e-mail: lonny@mbari.org
}

PЕЗЮМЕ: Sicyonis heliodiscus sp.n. и Hormathia pacifica sp.n. описаны из района подводных гор Тапеу в северо-восточнай Пацифике. Виды, относящиеся к этим двум родам, известны в основном из северной Атлантики и Антарктики, и только некото- 
рые из них найдены в Пацифике. Sicyonis heliodiscus sp.n. представляет собой очень крупную актинию, при жизни выглядящую нестандартно: короткий колюмн спрятан под широким оральным диском с короткими маргинальными щупальцами, направленными вниз. За 25 лет работ специалистами Исследовательского института Аквариума залива Монтерей было зарегистрировано всего лишь пять экземпляров этого редкого вида. Другой вид, Hormathia pacifica sp.n., наоборот, часто встречается в районе подводных гор Таnеy. Он имеет характерный для рода внешний вид и отличается от других видов рода Hormathia комбинацией признаков, включая внешнюю морфологию тела и книдом.

Как цитировать эту статью: Sanamyan N.P., Sanamyan K.E., Lundsten L. 2015. Two new deepwater sea anemones (Cnidaria: Anthozoa: Actiniaria) Sicyonis heliodiscus sp.n. (Actinostolidae) and Hormathia pacifica sp.n. (Hormathiidae) from Pacific // Invert. Zool. Vol.12. No.1. P.131-149. doi: 10.15298/invertzool.12.2.02

КЛЮЧЕВЫЕ СЛОВА: морские анемоны, актинии, Actiniaria, северная Пацифика, Taney Seamounts, абиссаль, Actinostolidae, Hormathiidae.

\section{Introduction}

Recent expeditions to seamounts in the northeast Pacific by scientists from the Monterey Bay Aquarium Research Institute (MBARI) have yielded numerous publications describing the geology (Clague et al., 2000; Davis et al., 2002; Clague et al., 2010; Davis et al., 2010), ecology (Lundsten et al., 2009; McClain et al., 2010; Lundsten et al., 2012; McClain, Lundsten, 2014), and new species (Cairns, 2007; Williams, Lundsten, 2009; Mah et al., 2010; Lundsten et al., 2014) found at these locations. These offshore, deep, and often unexplored locations provide a heterogeneous blend of depths and substrates that appear to elevate species diversity (McClain, Lundsten 2014).

Here we describe two species of anemones that were collected by remotely operated vehicle(ROV)Doc Ricketts at the Taney Seamounts, a chain of five aligned extinct volcanoes located on the Pacific Plate, approximately $270 \mathrm{~km}$ west of San Francisco in the Northeast Pacific Ocean (Clague et al., 2000) (Fig. 1). A recent description of the ecology of the Taney Seamounts was published by McClain, Lundsten (2014). In addition to the collected specimens, video observations that we presume could be attributed to these new species (based on morphological characteristics) from the Taney Seamounts and other locations in the North Pacific Ocean were used to better describe their habitat preferences and ecology.

\section{Material and methods}

Remotely operated vehicles (ROVs) were used to collect and observe specimens. Prior to collection, specimens were video taped in situ using either an Ikegami HDL-40 (ROV Doc Ricketts) or Panasonic WV-E550 (ROV Tiburon) video camera. Video observations were recorded to digital video tape and merged with ancillary data during post processing so that latitude, longitude, depth, temperature and oxygen concentration is known for every specimen collected or observed. When available, parallel red lasers $(640 \mathrm{~nm})$, spaced $29 \mathrm{~cm}$ apart, were used to estimate organism size in situ. Specimens were collected using ROV's manipulator arm and fixed in 10\% seawater formalin upon retrieval at the surface, then transferred to $70 \%$ ethanol for long-term storage. For the methods used to prepare histological sections see Sanamyan et al. (2013). Cnidae terminology follows Weill (1934) and Carlgren (1949), but classification of p-mastigophores follows Schmidt (1969, 1972a, 1974) with the modification of den Hartog (1995), for details see Sanamyan et al. (2012). Type material is stored 


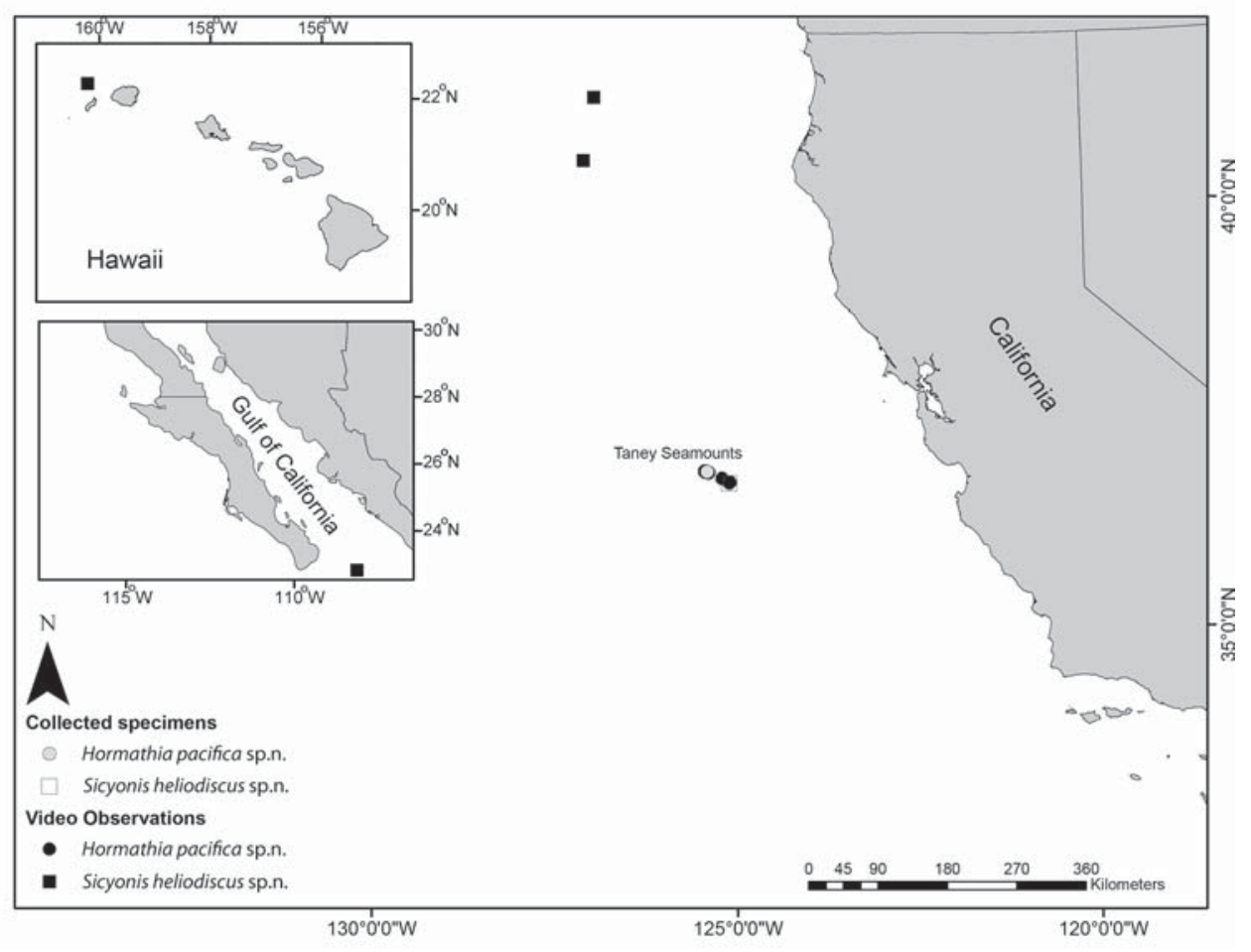

Fig. 1. A map showing locality of collected and observed specimens.

Рис. 1. Карта, показывающая местонахождения собранных и сфотографированных экземпляров.

at the Zoological Institute (ZIN) in St. Petersbourg, Russia. Using MBARI's Video Annotation and Reference System database (VARS, Schlining et al., 2006), we queried for additional observations of the species being described and include observational data for those that match the type specimens based on visible characteristics only.

\section{Taxonomy}

Order Actiniaria

Family Actinostolidae

Sicyonis heliodiscus sp.n.

Table 1; Figs. 2-6.

MATERIAL EXAMINED. Holotype: ZIN No.11334; MBARI No. D178-A27; NE Pacific, Taney Seamount C, $125.2517^{\circ} \mathrm{E}, 36.7178^{\circ} \mathrm{N}, 3178.6 \mathrm{~m}, 12.08 .2010$, collected by L. Lundsten.
DESCRIPTION. External structure. In situ photos of specimens show its very peculiar external appearance (Fig. 2). The body is low and disk shaped such that the column in live specimens is often almost completely hidden under the very wide oral disk, whose diameter in situ is estimated as $32.4 \mathrm{~cm}$. The tentacles are short and thick, with blunt and, occasionally, somewhat bulbous tips. They are arranged in two cycles on disk margin while the remaining surface of the oral disk does not has them. The marginal region of the oral disk together with the tentacles is bent downward and the tentacles are directed down and almost touch the substratum. The surface of the oral disk is more or less smooth in its central third but toward to the periphery is radially ridged: the mesenterial insertions are marked by radial furrows, the mesogloea over the endocoels is thickened and forms prominent radial ridges alternating with 

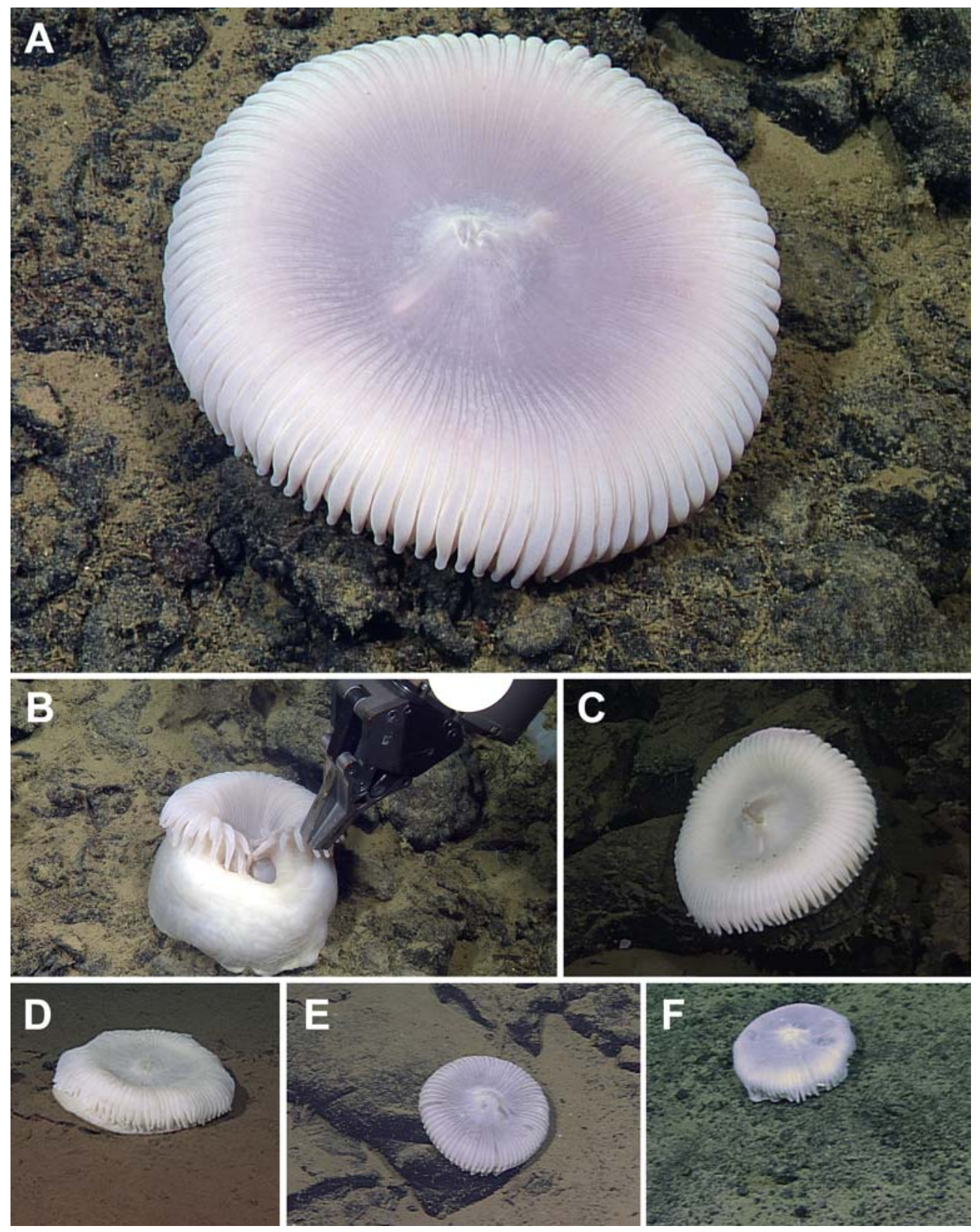

Fig. 2. Sicyonis heliodiscus sp.n., live specimens in natural habitat. A-B - the holotype; $\mathrm{C}-\mathrm{F}-$ four other observed (but not collected) specimens $\left(\mathrm{C}-22.8331^{\circ} \mathrm{N}, 108.1215^{\circ} \mathrm{W}, 3116 \mathrm{~m}, 16.04 .2003\right.$; D $41.1654^{\circ} \mathrm{N}, 127.4971^{\circ} \mathrm{W}, 3033 \mathrm{~m}, 15.08 .2000 ; \mathrm{E}-22.2788^{\circ} \mathrm{N}, 160.2175^{\circ} \mathrm{W}, 3762 \mathrm{~m}, 14.05 .2001 ; \mathrm{F}-$ $\left.40.4239^{\circ} \mathrm{N}, 127.6074^{\circ} \mathrm{W}, 2465 \mathrm{~m}, 23.08 .2001\right)$.

Рис. 2. Sicyonis heliodiscus sp.n., живые экземпляры в естественной среде обитания. А-В - голотип; $\mathrm{C}-\mathrm{F}$ - четыре других сфотографированных (но не собранных) экземпляра (C $-22.8331^{\circ} \mathrm{N}$, $108.1215^{\circ} \mathrm{W}, 3116 \mathrm{~m}, 16.04 .2003 ; \mathrm{D}-41.1654^{\circ} \mathrm{N}, 127.4971^{\circ} \mathrm{W}, 3033 \mathrm{~m}, 15.08 .2000 ; \mathrm{E}-22.2788^{\circ} \mathrm{N}$, $160.2175^{\circ} \mathrm{W}, 3762 \mathrm{м}, 14.05 .2001 ; \mathrm{F}-40.4239^{\circ} \mathrm{N}, 127.6074^{\circ} \mathrm{W}, 2465$ м, 23.08.2001). 


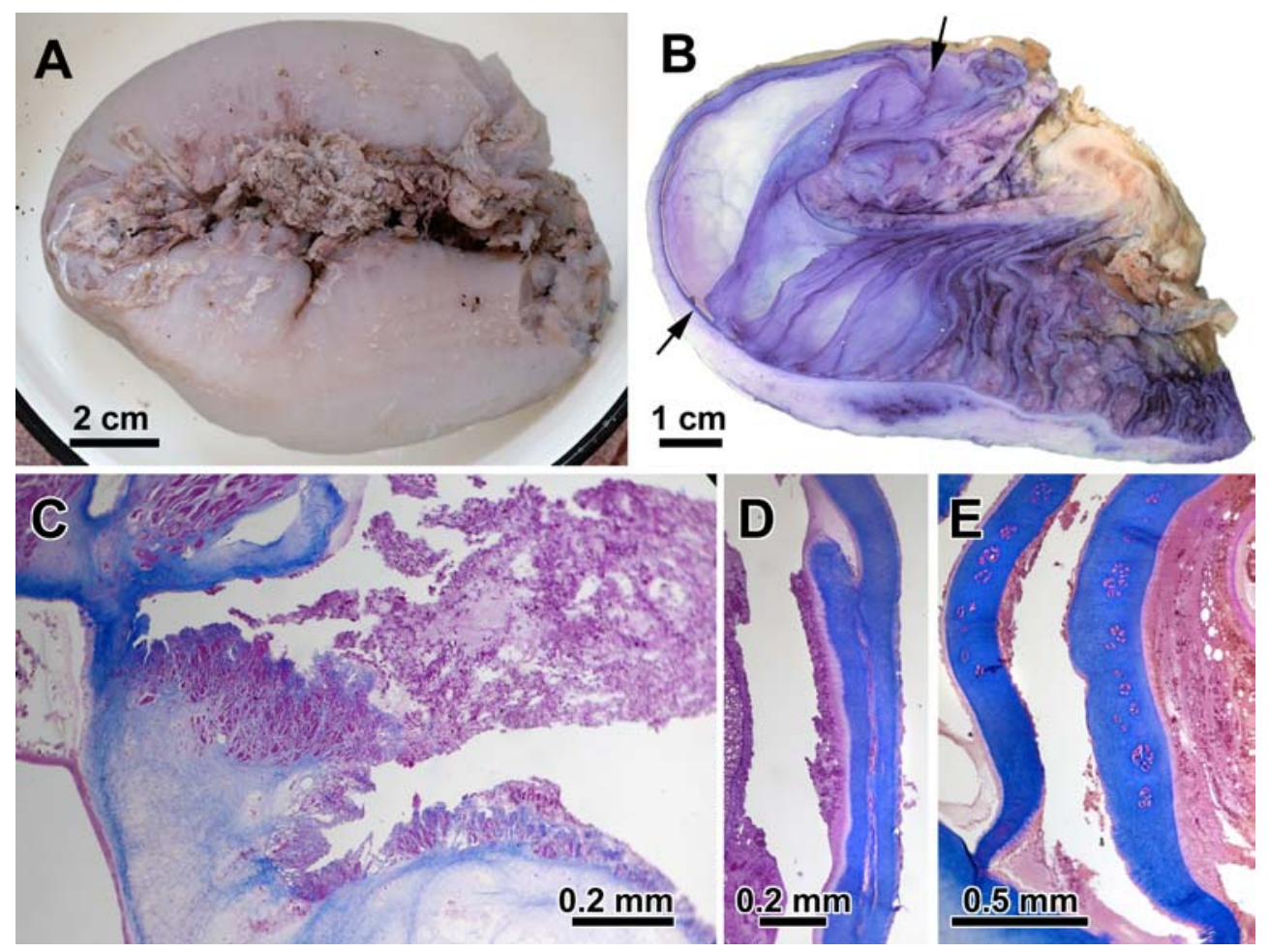

Fig. 3. Sicyonis heliodiscus sp.n. A - the holotype, whole specimen, top view; B — longitudinal (somewhat oblique) section of a half of the specimen, arrows indicate distal and proximal ends of the sphincter muscle, note relatively thin column in comparison with body size; $\mathrm{C}$ - retractor muscle in the distal (upper) part of the mesentery near its attachment to the oral disk; D - parietobasilar flap of sterile mesentery; E longitudinal muscle bands in the mesogloea of sterile mesenteries.

Рис. 3. Sicyonis heliodiscus sp.n. А - голотип, целый экземпляр, вид сверху; В - продольный (несколько косой) срез половины экземпляра, стрелками показаны дистальный и проксимальный концы сфинктера, отметьте сравнительно тонкую стенку колюмна по отношению к размерам тела; C - мускулы-ретракторы в дистальной (верхней) части мезентерия около его прикрепления к оральному диску; D - париетобазилярный выступ мезоглеальной пластинки стерильного мезентерия; Е - продольные мускульные тяжи в мезоглее стерильных мезентериев.

similar but lower ridges running over the exocoels (Figs 2A, 5D). All ridges running over endocoels are of the same width and height and it is not possible to distinguish endocoels of the first cycle from the ones of the second cycle, etc. The exocoels are narrower than the endocoels and they are all of the same width and height. In total, as counted on the photo, the collected specimen has 82 pairs of mesenteries inserted into the oral disk. So, it has 82 endocoelic tentacles (inner cycle) and 82 exocoelic tentacles (outer cycle - these are visible on Fig. 2B), making the total number of the tentacles 164 .
The number of tentacles in other recorded (but not collected) specimens is estimated from 134 to about 160 (Fig. 2C-F). The mouth is small and situated on a low elevation of the disk. The color of the living specimen is white. Two wide and not very clear whitish bands running at a short distance from the corner of the mouth probably correspond to siphonoglyphs.

The holotype was damaged when it was collected by the ROV manipulator (Fig. 2B), thus, preserved specimen has little resemblance to the living one (Fig. 3A). The holotype preserved in formalin is $15 \mathrm{~cm}$ in diameter and $6 \mathrm{~cm}$ 


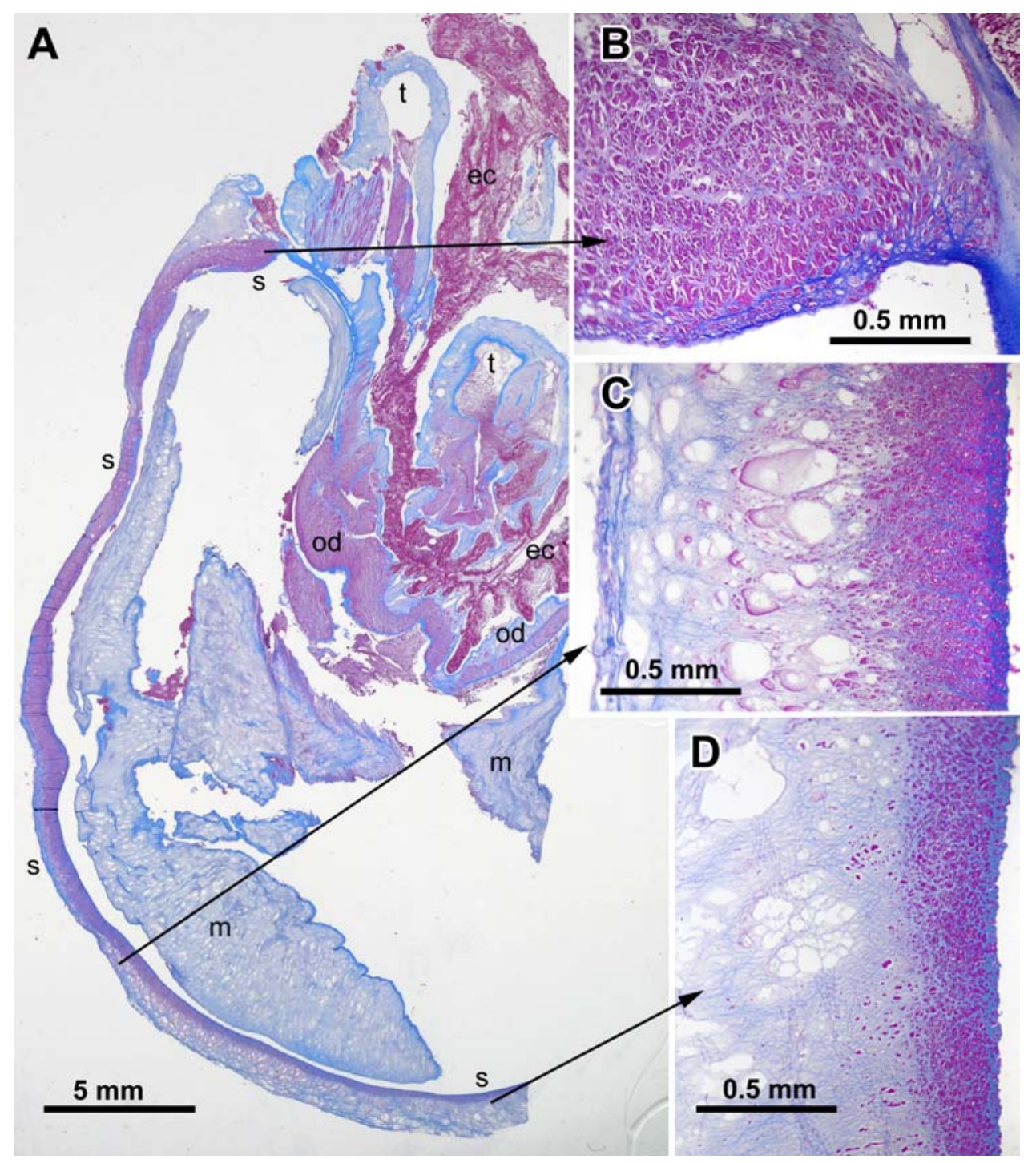

Fig. 4. Sicyonis heliodiscus sp.n., structure of the mesogloeal sphincter muscle. A - longitudinal section of the distal and middle column showing general appearance of sphincter muscle; B-D - details of distal, middle and proximal parts of the sphincter muscle, enlarged.

Abbreviations: ec - ectoderm of oral disk and tentacles; $\mathrm{m}$ - mesenteries; od — oral disk; $\mathrm{s}$ - marginal sphincter; $\mathrm{t}$ - tentacles.

Рис. 4. Sicyonis heliodiscus sp.n., структура мезоглеального сфинктера. А - продольный срез через дистальную и среднюю части колюмна, показывающий общий вид сфинктера; B-D - детали дистальной, средней и проксимальной частей сфинктера, увеличено.

Сокращения: ес - эктодерма орального диска и щупалец; $\mathrm{m}$ - мезентерии; od — оральный диск; s маргинальный сфинктер; $\mathrm{t}$ - щупальца.

in height. The surface of column is smooth, its ectoderm is abraded. Pedal disk is wide and round and greatly damaged, but the ectoderm is retained. The oral disk is closed but cannot completely cover the tentacles. The tentacles in preserved holotype are about $1.5 \mathrm{~cm}$ long and $0.5-0.7 \mathrm{~cm}$ in diameter, perforated at tip, inner and outer ones are of the same size. 
Internal structure. Mesogloea of the column is up to $5 \mathrm{~mm}$ thick in the proximal part of the body and up to $1 \mathrm{~mm}$ in distal part. It has spongy consistency with numerous lacunae and ruptures. The marginal mesogloeal sphincter muscle is mostly reticular and very long, up to 5 $\mathrm{cm}$ on longitudinal sections of the column (Figs $3 \mathrm{~B}, 4)$. It occupies almost the whole width of the mesogloea in the distal part and gradually narrows proximally binding to endodermal side of the mesogloea.

Radial muscles of the oral disk are mesogloeal and strong, not present along insertions of the mesenteries (Fig. 5D). The mesogloea of the contracted tentacles is of the same thickness on all sides, up to $2 \mathrm{~mm}$ at the base, thinner in other parts. Longitudinal musculature of the tentacles is mesogloeal, very strongly developed on the oral and weak on aboral side where muscle bands are thin, sparse or almost wanting (Fig. 5B). Longitudinal muscles in the tentacles are confined to endodermal side of the mesogloea. On the oral and lateral sides of the tentacles the inner (endodermal) half of the mesogloea containing strong muscle bands is torn from the outer half (probably because of strong contraction of muscle bands during collection or preservation of the specimen). On the aboral side of the tentacles the mesogloea is not torn. This condition was observed on all examined cross sections and is more evident toward the tentacle tip.

According to the number of tentacles the mesenteries in the distal part of column are probably arranged in five cycles (the fifth cycle is not complete). There are two pairs of directives. Perfect mesenteries are numerous (at least two cycles but probably more), but due to the condition of the specimen it is not possible to give exact number of perfect mesenteries and to determine their arrangement (hexamerous, octamerous, etc.). Additional (sixth) cycle of small mesenteries is present in the proximal part of column only (Fig. 5A). Mesenteries of this youngest cycle are fertile and lack filaments. All other mesenteries are sterile and bear filaments. Distal (upper) part of each sterile mesentery has greatly thickened mesogloea, up to about $2 \mathrm{~mm}$ on transverse sections, which rapidly narrows to a thin membrane $(30-100 \mu \mathrm{m})$ where the mesentery is attached to the column and to the oral disk (Fig. 5C). Retractor muscles are very weak and diffuse, with short mesogloeal processes (up to $50 \mu \mathrm{m}$ ). In most distal parts of the mesenteries, just below the oral disk, the retractor muscles are stronger and have processes two to three times longer (Fig. 3C). Parietobasilar muscles on some larger (sterile) mesenteries form a free, short flap up to $200 \mu \mathrm{m}$ long (Fig. $3 \mathrm{D})$. The outer (abaxial) part of larger mesenteries (closer to body wall), in the region of parietobasilar muscles, contains longitudinal mesogloeal muscle bands arranged into series in the middle of the mesogloea (Fig. 3E). Small fertile mesenteries of the youngest cycle have diffuse retractors with short mesogloeal processes up to about $30 \mu \mathrm{m}$. Mesogloea of the parietal part of these mesenteries is thickened and muscle processes here are longer, up to 50 $\mu \mathrm{m}$. Parietobasilar muscles of these mesenteries form short but distinct flap up to $60 \mu \mathrm{m}$ long (Fig. 5E). Mesenteries are probably not arranged according to the Actinostola-rule. There are small oral stomata (about $3 \mathrm{~mm}$ in diameter) and, probably, marginal stomata (no more than $1 \mathrm{~mm}$ in diameter). The examined specimen was a female and eggs were present with a diameter up to $1.5 \mathrm{~mm}$.

Cnidom. Cnidom includes gracile spirocysts, basitrichs, p-mastigophores A, p-mastigophores B1 (see Table 1 and Fig. 6). Ectoderm of pedal disk contains only one type of basitrichs (Fig. $6 \mathrm{~B})$. Basitrichs of two size ranges in column are unequally distributed: smaller ones (Fig. 6A) occur mostly at the distal column near the margin, while larger basitrichs (Fig. 6B) are common in proximal column and may form clusters near the limbus. The size ranges and types of cnidae in the ectoderm of the oral disk are the same as in tentacles. P-mastigophores in filament are of two types: p-mastigophores A (thin walled, no apical flaps) and p-mastigophores B1 (thick walled, with apical flaps) (Fig. 6H, I). These two types of p-mastigophores are of the same size range and have similar number of spiral turns on the shaft, 20-21 in p-mastigophores A and 17-19 in p-mastigophores B1. In 


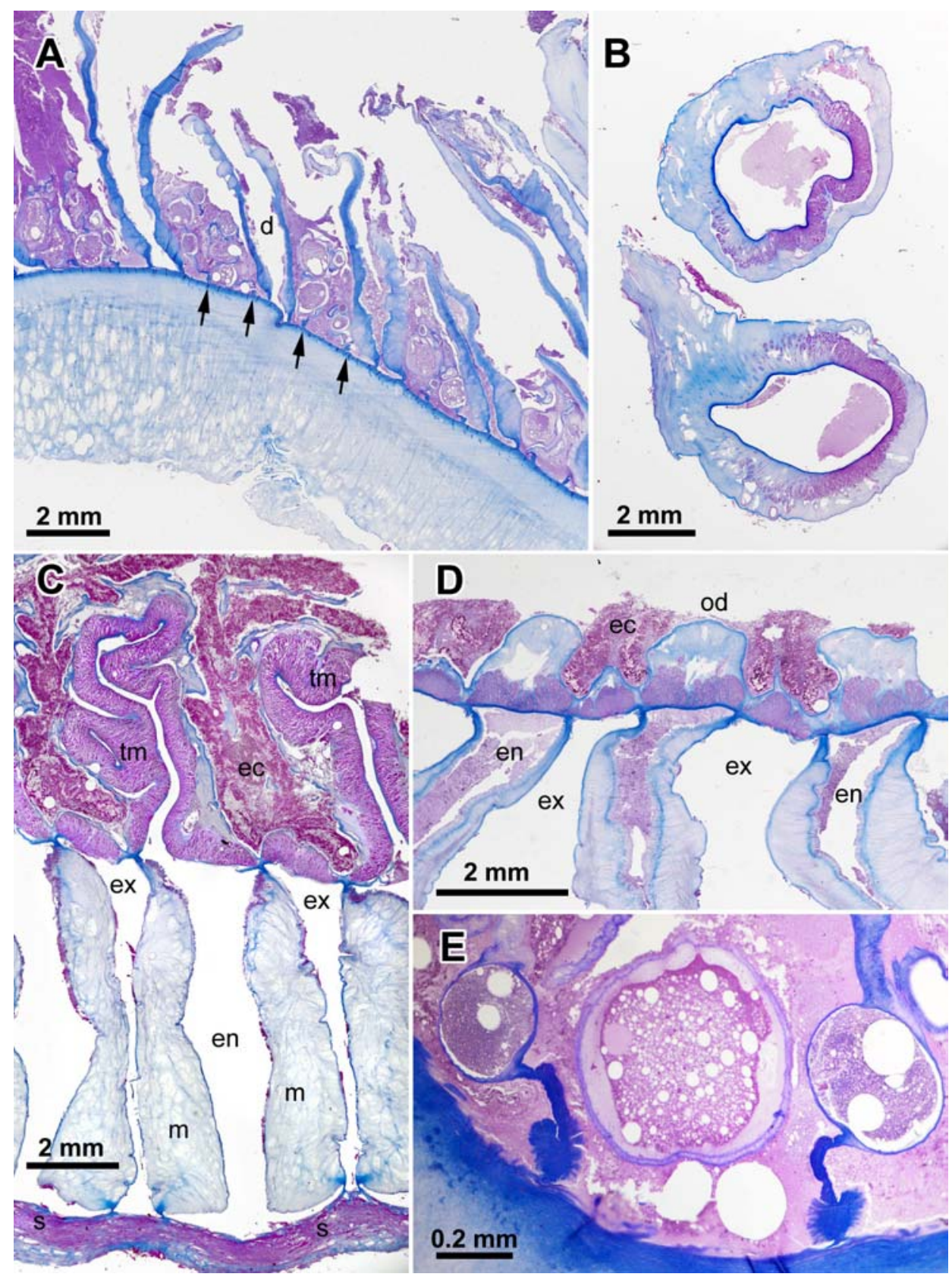

Fig. 5. Sicyonis heliodiscus sp.n., mesenteries and tentacles. A - transverse section of the middle part of the column to show large sterile mesenteries and small fertile mesenteries of the youngest cycle (arrows); B - transverse sections through the bases of the tentacles, thick mesogloea is ruptured by contraction of longitudinal mesogloeal muscles which are much better developed on the oral side of the tentacles; C transverse section through distal part of column showing very thick mesogloea in distal parts of mesenteries; note that mesenteries are connected to the column and the oral disk by a thin membrane; D - transverse section through middle part of the oral disk, note strong radial mesogloeal muscles interrupted at mesenterial insertions, thick mesogloeal ridges over endocoels and smaller ridges over exocoels; E - transverse section 


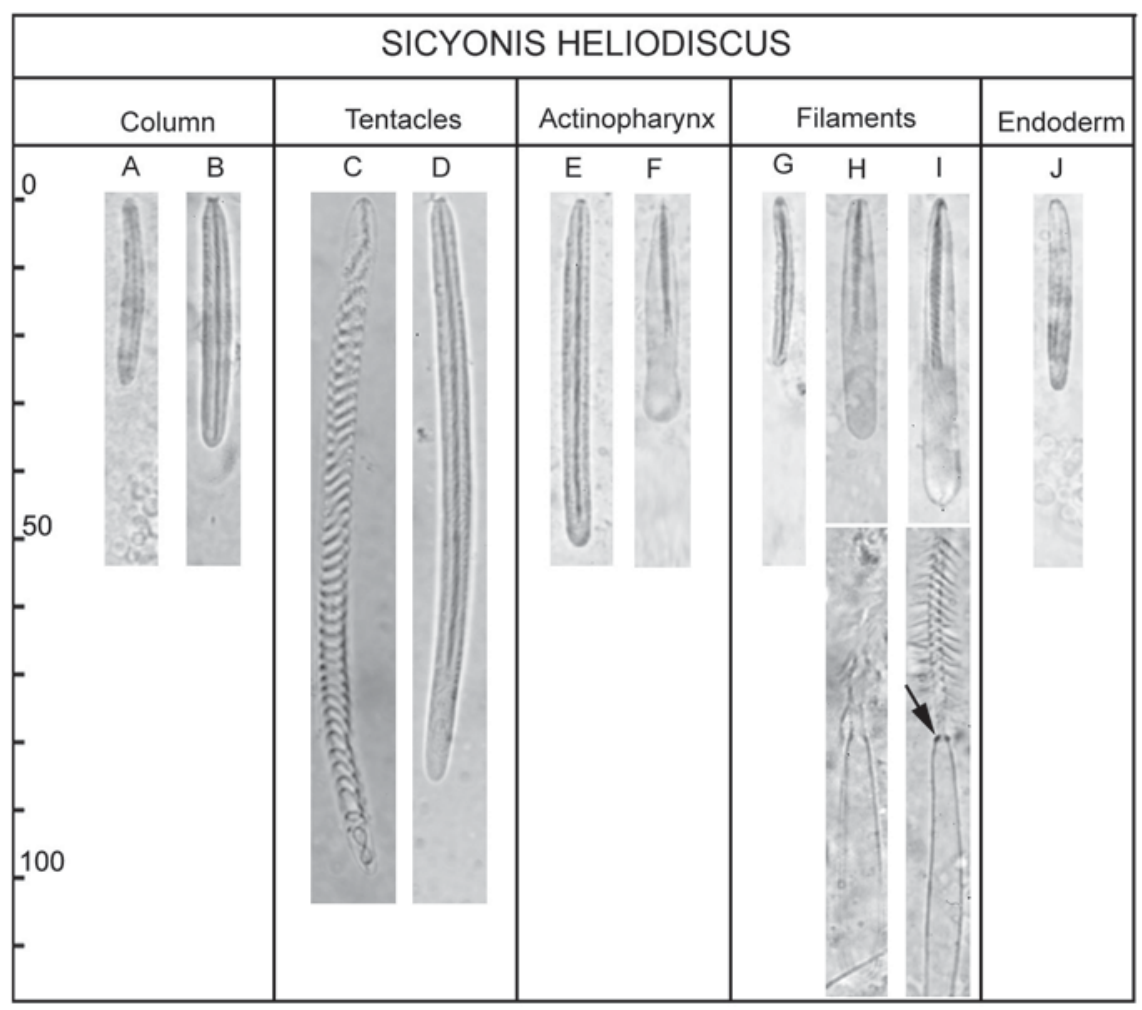

Fig. 6. Sicyonis heliodiscus sp.n., cnidom (see Table 1 for size ranges). Note presence of apical flaps in the exploded p-mastigophore B1 in filaments (arrow) and absence of such flaps in p-mastigophore A.

Рис. 6. Sicyonis heliodiscus sp.n., книдом (размеры указаны в табл. 1). Виден клапан в выстрелившем p-mastigophore B1 в филаменте (стрелка) и отсутствие клапана в p-mastigophore A.

of the proximal part of column showing a pair of fertile mesenteries of the youngest cycle, note significant development of parietal portion of longitudinal muscles.

Abbreviations: $\mathrm{d}$ - directives; ec - ectoderm of oral disk; en - endocoels; ex - exocoels; $\mathrm{m}$ - mesenteries; od oral disk; $\mathrm{s}-$ marginal sphincter; $\mathrm{tm}$ - longitudinal muscles in the bases of the tentacles.

Рис. 5. Sicyonis heliodiscus sp.n., мезентерии и щупальца. А - поперечный срез через среднюю часть колюмна, показывающий большие стерильные мезентерии и маленькие фертильные мезентерии последнего цикла (показаны стрелками); В - поперечный срез через основания щупалец; толстая мезоглея разорвана из-за сокращения продольных мезоглеальных мускулов, которые значительно лучше развиты на оральной стороне щупалец; С - поперечный срез через дистальную часть колюмна, показывающий мощные мезоглеальные утолщения дистальных концов мезентериев; мезентерии соединены с колюмном и оральным диском тонкой мембраной; D - поперечный срез через среднюю часть орального диска; видна сильная радиальная мезоглеальная мускулатура, прерванная в местах вхождения мезентериев, высокие мезоглеальные утолщения над эндоцелями и несколько меньшие утолщения поверх экзоцелей; Е — поперечный срез через проксимальную часть колюмна показывающий пару фертильных мезентериев последнего цикла; видна хорошо развитая париетальная часть продольной мускулатуры.

Сокращения: d - направляющие мезентерии; ес — эктодерма орального диска; en - эндоцели; еx — экзоцели; $\mathrm{m}$ - мезентерии; od - оральный диск; s — маргинальный сфинктер; tm - продольные мускулы в основаниях щупалец. 
Table 1. Size ranges (length $\times$ width, in microns) and distribution of cnidae in Sicyonis heliodiscus sp.n. Letters in brackets correspond to letters in Fig. 6.

Таблица 1. Размеры (длина $\times$ ширина, в микронах) и распределение стрекательных капсул Sicyonis heliodiscus sp.n. Буквы в скобках соответствуют обозначениям на рис. 6.

\begin{tabular}{llc}
\hline Body region & \multicolumn{1}{c}{ Cnidae } & Size ranges $(\mu \mathrm{m})$ \\
\hline \multirow{2}{*}{ Column } & (A) basitrichs (very rare) & $21-28 \times 2.5-3$ \\
& (B) basitrichs (few) & $30-53 \times 3-4$ \\
\hline \multirow{2}{*}{ Tentacles } & (C) spirocysts (very numerous) & $36-133 \times 2.5-5.5$ \\
& (D) basitrichs (common) & $52-100 \times 3.5-5$ \\
\hline \multirow{2}{*}{ Actinopharynx } & (E) basitrichs (numerous) & $41-67 \times 3-5$ \\
& (F) p-mastigophores A (rare) & $32-46 \times 5.5-6.5$ \\
\hline \multirow{2}{*}{ Filaments } & (G) basitrichs (common) & $22-30 \times 2-2.5$ \\
& (H) p-mastigophores A (rare) & $21-44 \times 5.5-7$ \\
\hline Endoderm & (I) p-mastigophores B1 (common) & $26-47 \times 4.5-6$ \\
\hline
\end{tabular}

exploded condition in all p-mastigophores the terminal tubule, when present, is short, about one capsule length.

HABITAT. Sicyonis heliodiscus sp.n. is a rare species, that have been collected once and observed on only four other occasions during more than 25 years of research by the Monterey Bay Aquarium Research Institute (Fig. 1). This species was observed at five Pacific Ocean locations including the Northwest Hawaiian Islands, the Gulf of California, off northern California, and the Taney Seamounts. One specimen was collected at Taney Seamount C. The specimen was firmly attached to manganese encrusted basaltic lava and breccia, the column was not buried and had no foreign particles attached to it (Fig. 2B). Sicyonis heliodiscus sp.n. is known in deep water from 2465 to 3762 $\mathrm{m}$ where oxygen (range $3.68-1.806 \mathrm{ml} / \mathrm{L}$ [and null at one station], avg. $2.18 \mathrm{ml} / \mathrm{L}, \mathrm{n}=5$ ) and temperature (range $1.621-1.827^{\circ} \mathrm{C}$, avg. $1.73^{\circ} \mathrm{C}, \mathrm{n}=5$ ) are low. Abundant Crinoidea, Enteropnuesta, Hexactinellida, Holothuroidea, and Ophiuroidea were observed in close proximity. Additional Actiniaria observed nearby included Hormathia pacifica sp.n. (described herein) and Liponema brevicorne (McMurrich 1893).

REMARKS. The genus Sicyonis currently contains 13 deep water species regarded as valid. Most of them are known from limited records and based on a few specimens. Only one species of Sicyonis has been described from NE Pacific, Sicyonis careyi Eash-Loucks et Fautin, 2012, and this species bears no resemblance with $S$. heliodiscus sp.n. Sicyonis careyi is much smaller, the tentacles are arranged in three cycles, nematocysts are two times smaller, mesenteries of the last cycle are much thinner and completely devoid of musculature (see EashLoucks, Fautin, 2012), while in S. heliodiscus sp.n. they are muscular.

Sicyonis tubulifera (Hertwig, 1882) was described from NW Pacific, off the east coast of Japan. According to Hertwig (1882: 129) it bears strong resemblance to Actinostola crassicornis (Hertwig, 1882) and has long, $3 \mathrm{~cm}$ tentacles, in preserved condition, that resemble "curved horns" arranged in four cycles while in the $S$. heliodiscus sp.n., which is much larger, the tentacles are short and arranged in two cycles. The sphincter of $S$. tubulifera is strong, much stronger than in $S$. heliodiscus sp.n., it "contracts the wall so strongly that the surface becomes arranged in ridge-like, projecting folds" (Hertwig, 1882: 129).

The remaining ten species of Sicyonis are not known from North Pacific. They include: two species, S. crassa Hertwig, 1882 and $S$. sumatriensis Carlgren, 1928 described from 
Indian Ocean, one, S. erythrocephala (Pax, 1922) that is widely distributed in Antarctic waters, and seven, S. gossei (Stephenson, 1918), S. variabilis Carlgren, 1921, S. tuberculata Carlgren, 1921, S. ingolfi Carlgren, 1921, S. obesa (Carlgren, 1934), S. hemisphaerica Carlgren, 1934 and S. biotrans Riemann-Zürneck, 1991 that are known only from North Atlantic. Of these ten species nine (all except $S$. gossei) can be easily distinguished from $S$. heliodiscus sp.n. by several features including the number and arrangement of tentacles (usually about two times less numerous than in S. heliodiscus sp.n. and sometimes distributed over whole oral disk as in S. erythrocephala), the shape of the body, and, especially, by size range of cnidae in tentacles. Basitrichs in the tentacles of S. heliodiscus sp.n. are significantly (about two or more times) longer than in all other Sicyonis species for which this feature is known. Sizes of cnidae are not known for $S$. gossei, and this species has about 150 tentacles but in contrast with S. heliodiscus sp.n. they are arranged in "three apparent cycles" (Stephenson, 1918a: 124). RiemannZürneck (1991) failed to trace the type specimen of this species to examine sizes of its nematocysts.

Riemann-Zürneck (1991: 9) reported that in Sicyonis biotrans "some of the fertile, smallest septa... carry trilobate mesenterial filaments but never unilobate ones." Using this feature as a basis, Eash-Loucks, Fautin (2012) moved this species to Parasicyonis, which is distinguished from Sicyonis by the presence of filaments on all mesenteries. There is a difference, however, in condition described for Parasicyonis species (e.g., P. sarsii Carlgren, 1921, the type species of Parasicyonis, or P. ingolfi Carlgren, 1942) in which most (or all?) mesenteries have filaments and the condition described for S. biotrans, in which most fertile mesenteries lack them but some may have filaments. We had an opportunity to examine a specimen of $S$. obesa from North Western Atlantic, in which one fertile mesentery had trilobate filament while all other fertile mesenteries were without them. It seems that occasional trilobate filaments may be present on fertile mesenteries of Sicyonis. Thus we prefer to leave Sicyonis biotrans in the genus Sicyonis.

In his key to genera of sea anemones Carlgren (1949) placed Sicyonis to the section entitled "Mesenteries indistinctly arranged according to the Actinostola-rule". Indeed, in some species of this genus mesenteries in some pairs are unequally developed, but in general it is not possible to say that they are arranged (even "indistinctly") according to the Actinostola-rule.

Eash-Loucks, Fautin (2012) reported holotrichs in S. careyi. These nematocysts are not present in S. heliodiscus sp.n. and not reported for other species of this genus. However, in $S$. heliodiscus sp.n. we observed incompletely exploded basitrichs in the tentacles with a broken off tubule which resemble holotrichs.

Sicyonis heliodiscus sp.n. is only the second species of Sicyonis to be observed in its natural habitat. The only other species of this genus photographed underwater is S. biotrans (see Riemann-Zürneck, 1991). In situ images reveal that the habitats of these two species are very different. Sicyonis biotrans was found in soft abyssal sediment of the NE Atlantic at depths from 4000 to $4800 \mathrm{~m}$ whereas $S$. heliodiscus sp. n. was found on hard, volcanic substrate at depths from 2465 to $3762 \mathrm{~m}$.

\section{Family Hormathiidae}

\section{Hormathia pacifica sp.n.}

Table 2; Figs. 7-10.

MATERIAL EXAMINED. Holotype: ZIN No.11335; MBARI No. D174-A7; NE Pacific, Taney Seamount A, $125.58095^{\circ} \mathrm{E}, 36.840596^{\circ} \mathrm{N}, 2882 \mathrm{~m}, 8.08 .2010$, collected by L. Lundsten.

DESCRIPTION. External structure. The body of preserved specimen (Fig. 8A) is $39 \mathrm{~mm}$ in height, more or less cylindrical with wider distal and proximal parts. Middle part of column is $18 \mathrm{~mm}$ in diameter. Pedal disk is wide, flattened, attached to small stone, somewhat concave but does not form a cavity. The column is divisible into scapus and scapulus. The scapus is $34 \mathrm{~mm}$ long and covered by brownish cuticle which is abraded on the tops of some tubercles. Numerous crowded tubercles on the 

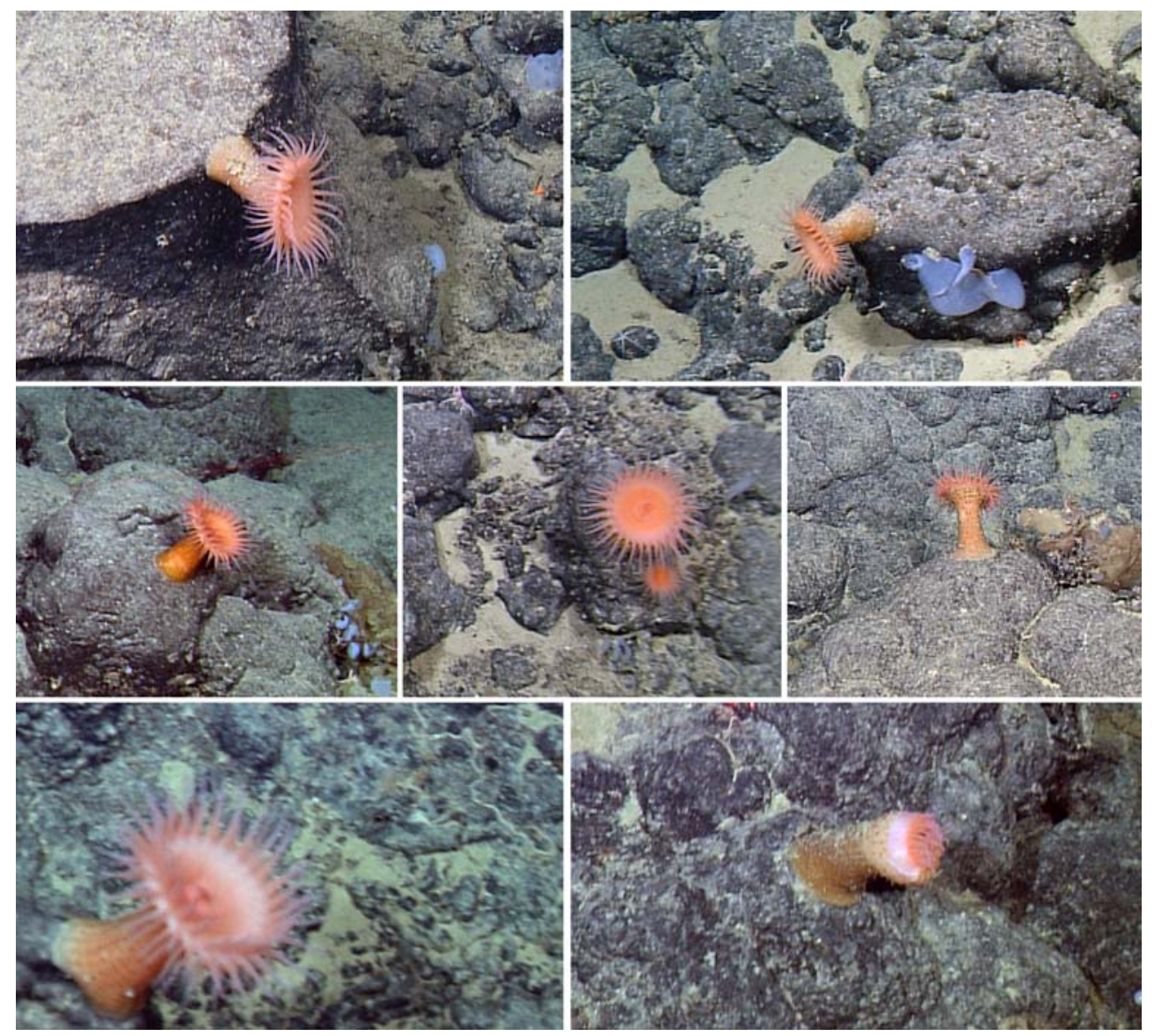

Fig. 7. Hormathia pacifica sp.n., live specimens in natural habitat (Taney Seamount).

Рис. 7. Hormathia pacifica sp.n., живые экземпляры в естественной среде обитания (Taney Seamount).

scapus are rather prominent and have rounded tops. On the distal part of scapus they are two times larger than the rest and are about $3 \mathrm{~mm}$ in diameter. Tubercles are arranged into not very regular vertical rows, about 29 rows distally and 34 proximally. Coronal tubercles were not present. The scapulus is $7-8 \mathrm{~mm}$ long and not covered by cuticle. Twenty-four low scapular ridges are distinguishable, each having one or two tubercles in its proximal part.

The oral disk and tentacles are hidden by distal column in the preserved specimen. The tentacles are up to $4 \mathrm{~mm}$ long and $1.5 \mathrm{~mm}$ in diameter, without mesogloeal thickenings at bases, about 85 in the examined specimen.
The live specimens on numerous underwater photos taken at the Taney Seamounts (Fig. 7) look quite uniform and do not show any noticeable degree of variability in size, shape and color. The body of live specimens is more or less cylindrical, with proximal and distal parts of column being wider than its middle part. The base is wide and circular, attached to bare parts of stones, not covered by sediment. Oral disk is circular, when extended about two times greater than the diameter of column. The tentacles are tapered, pointed, about the same length as the radius of the oral disk, distributed on the margin of the oral disk in three cycles: $24+24+$ up to 48 . Tubercles on the scapus are arranged into dis- 


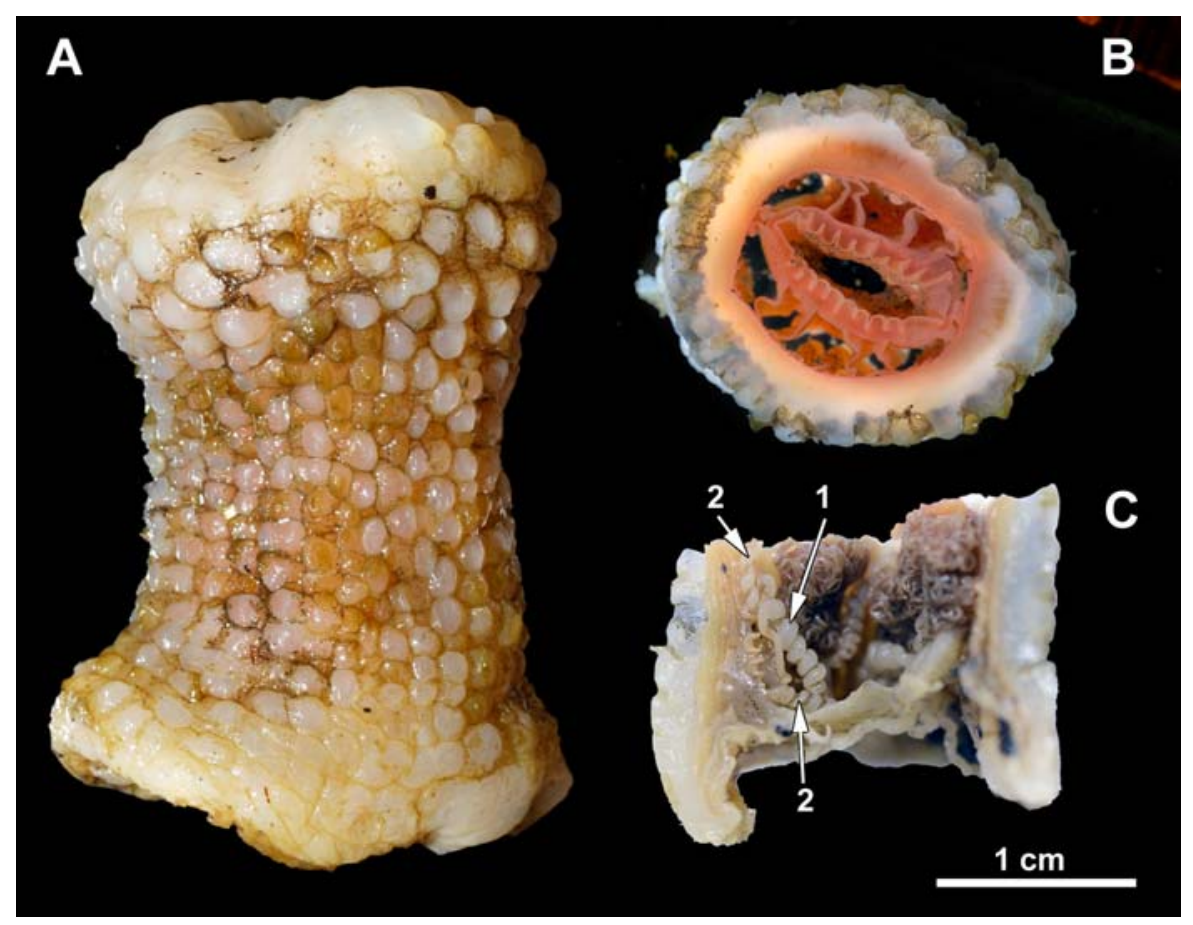

Fig. 8. Hormathia pacifica sp.n., holotype. A — intact specimen, side view; B — transverse section through the middle part of the column; $\mathrm{C}$ - longitudinal section of the proximal part of the column to show acontia; numbers indicate acontia on the mesenteries of the first and the second cycles.

Рис. 8. Hormathia pacifica sp.n., голотип. А - целый экземпляр, вид сбоку; В - поперечный срез через среднюю часть колюмна; С - продольный срез через проксимальную часть клюмна, цифрами обозначены аконтии на мезентериях первого и второго циклов.

tinct longitudinal rows and reach the limbus. The oral disk and tentacles are pink or salmon colored, the coloration of the central part of the oral disk and the bases of the tentacles is usually somewhat more intense. The scapulus is pale pink, the tint of the scapus is more brownish due to the presence of cuticle. In freshly preserved specimen the actinopharynx and mesenteries were bright red (Fig. 8B), however, the color faded after a few years of preservation (Fig. 8C).

Internal structure. Mesogloea of column is thick, up to $3 \mathrm{~mm}$ on tubercles in the middle part of the scapus. Ectoderm and endoderm are thin, 20-50 $\mu \mathrm{m}$.

Mesogloeal marginal sphincter muscle is alveolar (Fig. 9A,B). In the distal part of the scapulus it is wide and occupies almost the whole width of mesogloea. The sphincter gradually narrows proximally and extends to a short distance $(1.5 \mathrm{~mm})$ to the distal part of the scapus. On transverse sections through the sphincter the individual muscle meshes are sparse and well spaced, at its proximal end they are arranged into a single series and at distal end of the sphincter they extend up to the bases of the tentacles. The sphincter is separated from endoderm by a fairly wide layer of mesogloea, with its narrow, proximal end closer to the ectodermal side (Fig. 9A). Circular endodermal muscles are rather strong in most parts of the scapus and weaker in the distal part of the column. Longitudinal muscles of the tentacles and radial muscles of the oral disk are ectodermal.

The actinopharynx extends to the middle of the column and has thick (up to $0.6 \mathrm{~mm}$ ) mesogloea. It has two clear but shallow siphonoglyphs supported by directives and about 20 deep longitudinal furrows (Fig. 8B). 


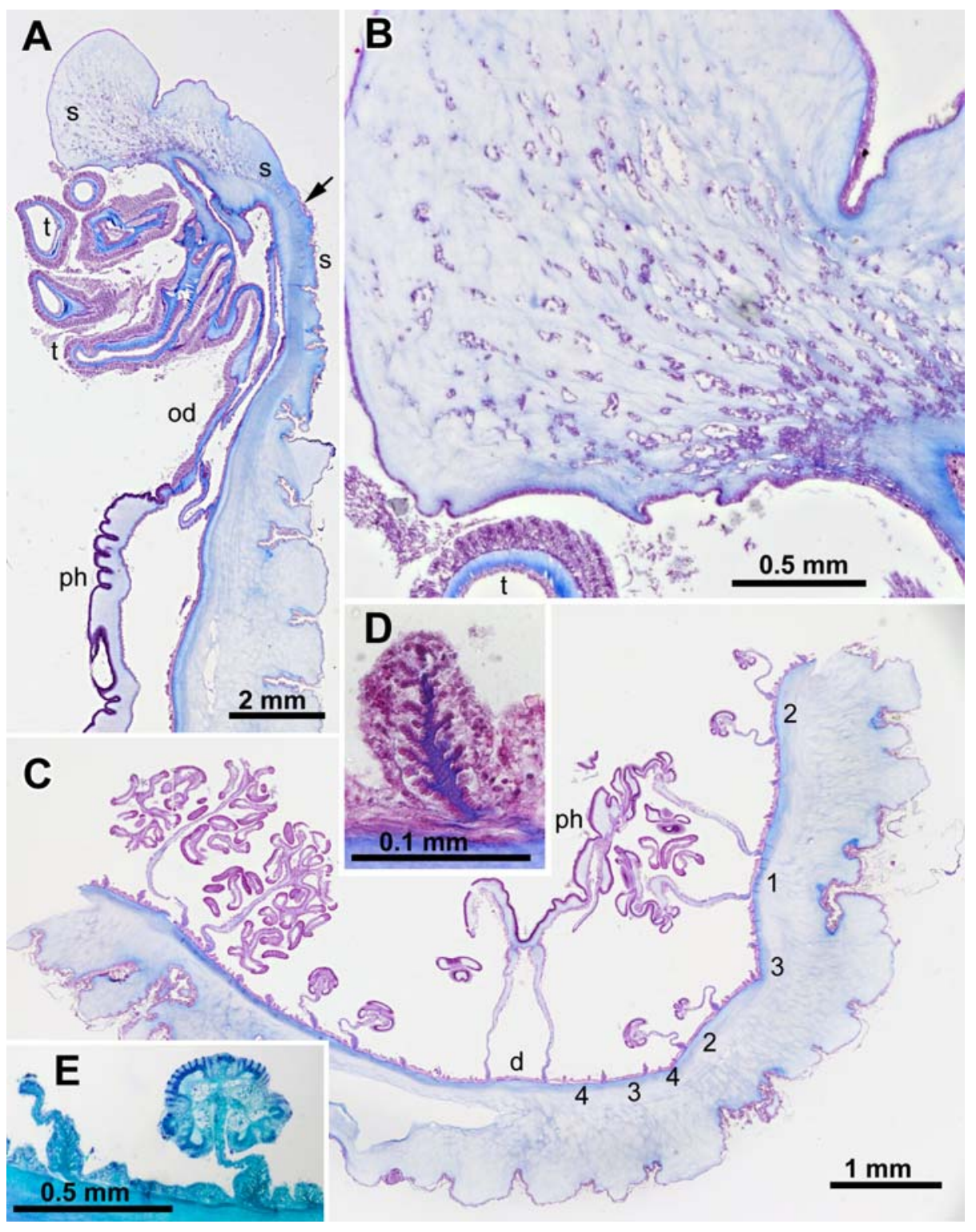

Fig. 9. Hormathia pacifica sp.n., histological sections. A - longitudinal section through the distal part of the column (arrow indicates the boundary between the scapus and scapulus); B - distal portion of the mesogloeal marginal sphincter; $\mathrm{C}$ - transverse section through the middle part of the column showing arrangement of the mesenteries, the numbers indicate the cycles of mesenterieal pairs; D - mesentery of the fourth cycle; E - a pair of mesenteries of the third cycle in the proximal part of the column.

Abbreviations: $\mathrm{d}$ - directives; od — oral disk; $\mathrm{ph}$ - actinopharynx; $\mathrm{s}$ - marginal sphincter; $\mathrm{t}$ - tentacles.

Рис. 9. Hormathia pacifica sp.n., гистологические срезы. А - ппродольный срез через дистальную часть колюмна (стрелкой показана граница между скапусом и скапулюсом); В - дистальная часть маргинального сфинктера; C - поперечный срез через среднюю часть колюмна, показывающий организацию мезентериев; цифры обозначают номера циклов пар мезентериев; D - мезентерий четвертого цикла; Е - пара мезентериев третьего цикла в проксимальной части колюмна.

Сокращения: $\mathrm{d}$ - направляющие мезентерии; od — оральный диск; ph - актинофаринкс; s — маргинальный сфинктер; $\mathrm{t}$ - щупальца. 


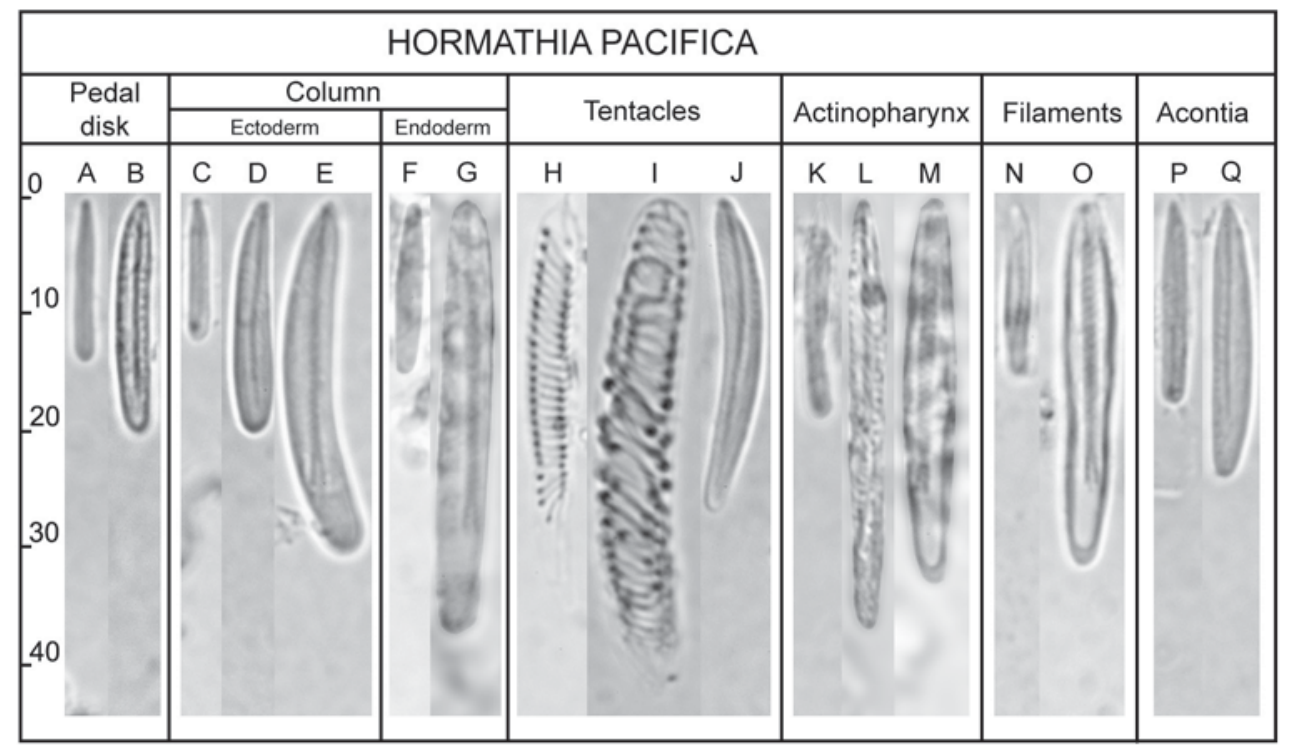

Fig. 10. Hormathia pacifica sp.n., cnidom (see Table 2 for size ranges).

Рис. 10. Hormathia pacifica sp.n., книдом (размеры указаны в табл. 2).

Table 2. Size ranges (length $\times$ width, in microns) and distribution of cnidae of Hormathia pacifica sp.n. Letters in brackets correspond to letters in Fig. 10.

Таблица 2. Размеры (длина $\times$ ширина, в микронах) и распределение стрекательных капсул Hormathia pacifica sp.n. Буквы в скобках соответствуют обозначениям на рис. 10.

\begin{tabular}{llc}
\hline Body region & \multicolumn{1}{c}{ Cnidae } & Size ranges $(\mu \mathrm{m})$ \\
\hline \multirow{2}{*}{ Pedal disk } & (A) basitrichs (common) & $10-17 \times 1.5-2$ \\
& (B) basitrichs (common) & $15-23 \times 2.5-3$ \\
\hline \multirow{3}{*}{ Column ectoderm } & (C) basitrichs (few) & $10-13 \times 1-2$ \\
& (D) basitrichs (common) & $15-22 \times 2.5-4$ \\
& (E) p-mastigophores B2a (few) & $25-35 \times 4-5$ \\
\hline \multirow{2}{*}{ Column endoderm } & (F) basitrichs (few) & $11-19 \times 1.5-2$ \\
& (G) p-mastigophores B1 (common) & $29-39 \times 3.5-5$ \\
\hline \multirow{3}{*}{ Tentacles } & (H) gracile spirocysts (numerous) & $27-51 \times 3-6$ \\
& (E) robust spirocysts (numerous) & $25-60 \times 5-10.5$ \\
& (J) basitrichs (common) & $20-31 \times 2.5-3.5$ \\
\hline \multirow{3}{*}{ Actinopharynx } & (K) basitrichs (few) & $11-21 \times 1.5-2$ \\
& (L) basitrichs (common) & $29-40 \times 2.5-3.5$ \\
\hline \multirow{2}{*}{ Filaments } & (M) p-mastigophores B1 (numerous) & $26-40 \times 3.5-5$ \\
\hline \multirow{2}{*}{ Acontia } & (N) basitrichs (few) & $12-19 \times 1.5-2$ \\
& (O) p-mastigophores B1 (common) & $25-34 \times 3.5-4.5$ \\
\hline
\end{tabular}


The mesenteries are arranged hexamerously in four cycles: $6+6+12+24$ (Fig. 9C). The number of mesenteries is the same distally and proximally. Only mesenteries of the first cycle are perfect. The mesenteries of the fourth cycle are small and have no distinguishable retractors and filaments (Fig. 9D). The mesenteries of the third cycle have only trilobate filaments in the proximal part of the column (Fig. 9E). The mesenteries of the first and the second cycle have well developed filaments (trilobate and unilobate) and acontia. Acontia are well developed (Fig. 8C), rather thick along most of their length but become gradually thinner toward their proximal ends (by which they are attached to the mesenteries). In these thinner parts acontia have almost no large basitrichs (Fig. 10Q), which are present in the remaining part of acontia. Acontia on the first cycle of the mesenteries are thicker $(0.5 \mathrm{~mm}$ in diameter $)$ than those of the second cycle $(0.3 \mathrm{~mm})$ (Fig. $8 \mathrm{C})$. Retractors are diffuse and very weak, better developed on distal parts of the mesenteries and distinguishable only on the mesenteries of the first and the second cycles. Parietobasilar muscles are hard to recognize. Parietal part of longitudinal musculature of all mesenteries is well developed. Marginal stomata are about $0.5 \mathrm{~mm}$ in diameter, oral stomata not found.

The examined specimen was sterile.

Cnidom. Cnidom includes gracile and robust spirocysts, basitrichs, p-mastigophores B1, p-mastigophores B2a. Ectoderm of the limbus, the scapus, and the scapulus contains two sorts of basitrichs and bilaterally symmetric p-mastigophores B, which, according to Hartog (1995), should be assigned to category B2, although the 'faltstuck' of the shaft in exploded capsules is not recognizable. The endoderm of column contains p-mastigophores B1 (Fig. 10G) of the same type as in ectoderm of actinopharynx and filaments (Fig. 10M, O). They are radially symmetrical, have no 'faltstuck' and terminal tubule. These p-mastigophores are not present in the endoderm of mesenteries, tentacles, oral disk and actinopharynx, where only small sparse basitrichs (Fig. 10F) are present. Cnidoglandular tracts of filaments contain basitrichs and p- mastigophores B1. The endoderm of mesenteries just behind the filament contains only basitrichs (as on Fig. 10N), which are more numerous closer to cnidoglandular tracts of filaments. The digestive region of the mesenteries behind unilobate filaments also contains groups of spirocysts and large nematocysts, which are not known in Actiniaria. They were not correctly orientated in the tissue, sometimes crumpled and should be considered as contaminants from the prey.

HABITAT. Hormathia pacifica sp.n. appears to be rather common at the Taney Seamounts where 66 specimens were documented photographically. This species was observed in situ at the Taney Seamounts living upon manganese encrusted basalt and, also, dead sponge tissue. Several species of Asteroidea, Crinoidea, Holothuroidea, Ophiuroidea, Porifera were observed living in close proximity to $H$. pacifica sp.n. Specimens were observed in deep water from 2142 to $3156 \mathrm{~m}$. Temperature (average $1.6{ }^{\circ} \mathrm{C} \pm 0.07^{\circ} \mathrm{C}, \mathrm{n}=66$ ), oxygen concentration $(2.17 \mathrm{ml} / 1 \pm 0.22 \mathrm{ml} / 1$ std. dev., $\mathrm{n}=66)$, and salinity (34.6 psu \pm 0.01 psu std. dev., $\mathrm{n}=64$ ) varied little and appear to be normal values for these depths at this location.

REMARKS. The genus Hormathia comprises many nominal species. Some of these species are well known while the validity of the others requires confirmation. The species of this genus can be distinguished from very similar Actinauge by the absence of mesogloeal thickening on the bases of the tentacles. Also the species belonging to Actinauge tend to have modified base embracing a ball of mud or clamping elongated objects like polychaete tubes or branches of gorgonarians, while Hormathia species usually have flattened circular base. Unlike Phelliactis and Paraphelliactis the number of cycles of mesenteries in Hormathia never exceeds four, and species of Hormathia never have more than 96 tentacles.

Geographically Hormathia species may be divided into two groups: a group that includes northern species known mainly from Arctic and North Atlantic and a group of southern species known mainly from Antarctic and sub-Antarctic waters and Chile. 
Two northern species, $H$. digitata (Müller, 1776) and H. nodosa (Fabricius, 1780) are the most well known species of this genus. Both can be easily distinguished from the present species by the structure of column and appearance of tubercles: H. pacifica sp.n. has no coronal tubercles (which are present in $H$. digitata), and large spaced tubercles of $H$. nodosa are very different from those of $H$. pacifica sp.n. Hormathia coronata (Gosse, 1858), known mainly from Mediterranean and NE Atlantic, has distinct coronal tubercles. Size ranges of nematocysts of these three species differ from those of the present species, e.g. large basitrichs in acontia are larger than in H. pacifica sp.n.

The remaining northern species are poorly known and their taxonomic position is not always clear:

Hormathia josefi Zhiubikas, 1977 is known only from original description based on several specimens from Frantz Josef Land (Arctic), its body is smooth and large basitrichs in acontia are larger than in $H$. pacifica sp.n. Grebelnyi (1980) synonymized this species and H. nodosa with $H$. digitata.

Hormathia alba (Andres, 1881) (originally described as Phellia nummus var. alba) was recorded in Mediterranean and Morocco coast and in Canary Islands (Ocaña, Hartog, 2002). Schmidt (1972b) probably considered this species as a synonym of $H$. coronata: he synonymized Phellia nummus Andres, 1881 with $H$. coronata (although var. alba was not mentioned explicitly) and H. alba is not listed in his monograph on Mediterranean anemones.

Hormathia incubans (Gravier, 1918) is known only from the type specimen described from North Sea. It has coronal tubercles, and large basitrichs in acontia are larger than in $H$. pacifica sp.n. (see Gravier, 1922; Carlgren, 1934). According to Carlgren (1934) this species is most probably conspecific with $H$. digitata.

Hormathia marioni (Haddon, 1889) is known only from original description based on one specimen from NE Atlantic. The basal disk of this specimen embraced a spine of sea urchin and the species may be more related to $A c$ - tinauge than to Hormathia. The external appearance of this species, as figured and described by Haddon (1889), is very different from $H$. pacifica sp.n.

The southern group of Hormathia includes the following species:

Hormathia lacunifera (Stephenson, 1918) is widely distributed in Antarctic and sub-Antarctic waters and was re-described in detail by several recent authors (Dunn, 1983; Rodríguez, López-González, 2013; Sanamyan et al., 2015). This species differs from $H$. pacifica sp.n. quite distinctly in live and in preserved condition; in particular it has more flattened rectangular tubercles (see Rodríguez, López-González, 2013; Sanamyan et al., 2015). Cnidom also presents substantial differences, in particular the large basitrichs in acontia are much larger than those of $H$. pacifica sp.n. and p-mastigophores in the actinopharynx are of different type (most pmastigophores in the actinopharynx of $\mathrm{H}$. lacunifera are thin-walled p-mastigophores $\mathrm{A}$, see Sanamyan et al., 2015).

Hormathia georgiana Carlgren, 1927 from South Georgia resembles both $H$. lacunifera and $H$. armata. It was synonymized with $H$. lacunifera by Rodríguez, López-González (2013).

Hormathia insignis (Stephenson, 1918) from the entrance to McMurdo Sound was regarded as a probable synonym of $H$. lacunifera by Rodríguez, López-González (2013). It lacks well defined rounded tubercles as in $\mathrm{H}$. pacifica sp.n., its column was described by Stephenson (1918b: 57) as "smooth and firm [...], deeply wrinkled transversely and less distinctly longitudinally, so that it is broken up into numerous little roughly rectangular areas".

Hormathia armata Rodríguez et LópezGonzález, 2001 is known from the Weddell Sea and Antarctic peninsula. It has acuminate tubercles on the column (regarded by Rodríguez, López-González, 2001 as one of the species specific feature) rather than rounded tubercles in H. pacifica sp.n. and large basitrichs in acontia of this species are more than two times larger than in H. pacifica sp.n.

Hormathia pectinata (Hertwig, 1882) is known from Chilean and Argentinean coasts of 
South America. The holotype of this species was examined by Rodríguez, López-González (2001). This species has 12 rows of coronal tubercles and different cnidom (among other differences, the large basitrichs in acontia are larger than those of $H$. pacifica sp.n.).

Hormathia castanea (McMurrich, 1904) is known from Chile. It was synonymized with $H$. pectinata by Rodríguez, López-González (2013). Large basitrichs in acontia in this species are larger than in H. pacifica sp.n.

Hormathia spinosa (Hertwig, 1882) is based on specimens (syntypes) from two distant Challenger stations, one in SE Indian Ocean and another in NW Pacific off Japan. According to Hertwig (1882) his species has acuminated tubercles (rather than rounded as in $H$. pacifica sp.n.). Cnidom of one syntype specimen (from the Indian Ocean location) of this species was examined by Rodríguez, López-González (2001), it differs from cnidom of $H$. pacifica sp.n.

Hormathia andersoni Haddon, 1888 is a poorly known shallow water species described from warm tropical waters (Indonesia) that cannot be identical with $H$. pacifica sp.n.

Thus, H. pacifica sp.n. cannot be assigned to any known Hormathia species and despite the fact that only one specimen was collected we describe it as a new species here. Its most important distinguishing features are numerous crowded rounded tubercles on the column arranged into many longitudinal rows, absence of coronal tubercles and cnidom; in particular, the larger basitrichs in acontia are smaller than in all other Hormathia species for which this character is known. Also, an interesting feature of this species is the presence in the endoderm of the column of the large p-mastigophores B, while usually in other species the endoderm contains only sparse basitrichs.

\section{ACKNOWLEDGMENTS}

We are grateful for support from the pilots of the ROVs Doc Ricketts and Ventana and the crews of the R/Vs Western Flyer and Rachel Carson. We appreciate the comments from reviewers who greatly improved this manuscript.
This work was partially supported by the David and Lucile Packard Foundation's funding of MBARI.

\section{References}

Eash-Loucks W.E., Fautin D.G. 2012. Taxonomy and distribution of sea anemones (Cnidaria: Actiniaria and Corallimorpharia) from deep water of the northeastern Pacific // Zootaxa. Vol.3375. P.1-80.

Carlgren O. 1934. Zur Revision des Actiniarien // Arkhiv för zoologi. Bd.26A. H.18. S.1-36.

Carlgren O. 1949. A survey of the Ptychodactiaria, Corallimorpharia and Actiniaria // Kungliga Svenska Vetenskapsakadamiens Handlingar. Vol.1. P.1-121.

Cairns S.D. 2007. Calcaxonian octocorals (Cnidaria: Anthozoa) from eastern Pacific seamounts // Proceedings of the California Academy of Sciences. Vol.58. P.511541.

Clague D.A., Reynolds J.R., Davis A.S. 2000. Near-ridge seamount chains in the northeastern Pacific Ocean // Journal of Geophysical Research. Vol.105. P.1654116561.

Clague D., Lundsten L., Hein J., Paduan J., Davis A. 2010. Spotlight 6: Davidson Seamount // Oceanography. Vol.23. No.1. P.126-127.

Davis A.S., Clague D., Bohrson W.A., Dalrymple G.B., Greene H.G. 2002. Seamounts at the continental margin of California: a different kind of oceanic intraplate volcanism // Geological Society of America Bulletin. Vol.114. P.316-333.

Davis A.S., Clague D.A., Paduan J.B., Cousens B.L., Huard J. 2010. Origin of volcanic seamounts at the continental margin of California related to changes in plate margins // Geochemistry, Geophysics, Geosystems. Vol.11. No.5. Q05006, P.1-28.

Dunn D.F. 1983. Some Antarctic and sub-antarctic sea anemones (Coelenterata: Ptychodactiaria and Actiniaria) // Biology of the Antarctic Seas 14. Antarctic Research Series. Vol.39. P.1-67.

Gravier C. 1922. Hexactinidés provenant des campagnes des yachts Hirondelle I et II et Princesse-Alice I et II (1888-1913) // Resultats Campagnes scientifiques accomplies sur son yacht par Albert I Prince Souverain de Monaco. Fasc.63. P.1-105.

Grebelnyi S.D. 1980. [On the northern representatives of the genus Hormathia (Hormathiidae, Actiniaria)] // Explorations of the fauna of the seas. Leningrad: Nauka. Vol.15(33). P.12-28 [in Russian].

Hartog J.C., den. 1995. The genus Telmatactis Gravier, 1916 (Actiniaria: Isophellidae) in Greece and the eastern Mediterranean // Zoologische Mededelingen, Leiden. Vol.69. No.14. P.153-176.

Haddon A.C. 1889. A revision of the British Actiniae. Part $1 / /$ Scientific Transactions of the Royal Dublin Society. Vol.4. Ser.2. P.297-361.

Hertwig R. 1882. Report on the Actiniaria dredged by H.M.S. Challenger during the years 1873-1876 // 
Scientific Results of the Voyage of H.M.S. Challenger. Zoology. Vol.7. No.2. P.1-136.

Lundsten L., Barry J.P., Cailliet G.M., Clague D.A., DeVogelaere A.P., Geller J.B. 2009. Benthic Invertebrate Communities on Three Seamounts off Southern and Central California, USA // Marine Ecology Progress Series. Vol.374. P.23-32.

Lundsten L., Johnson S.B., Cailliet G.M., DeVogelaere A.P., Clague D.A. 2012. Morphological, molecular, and in situ behavioral observations of the rare deepsea anglerfish Chaunacops coloratus (Garman 1899), Order Lophiiformes, in the eastern North Pacific // Deep-Sea Research I. Vol.68. P.46-53. 10.1016/ j.dsr.2012.05.012.

Lundsten L., Reiswig H.M., Austin W.C. 2014. Four new species of Cladorhizidae (Porifera, Demospongiae, Poecilosclerida) from the Northeast Pacific // Zootaxa. Vol.3786. No.2. P.101-123.

Mah C., Nizinski M., Lundsten L. 2010. Phylogenetic Revision of the Hippasterinae (Goniasteridae; Asteroidea): Systematics of Deep Sea Corallivores, including one new genus and three new species // Zoological Journal of the Linnean Society. Vol.160. P.266-301.

McClain C.R., Lundsten L., Barry J.P., DeVogelaere A.P. 2010. Assemblage structure, but not diversity or density, change with depth on a northeast Pacific seamount // Marine Ecology. Vol.31. Suppl.1. P.1-12.

McClain C.R., Lundsten L. 2014. Assemblage structure is related to slope and depth on a deep offshore Pacific seamount chain // Marine Ecology. doi: 10.1111/ maec. 12136.

Ocaña O., Hartog J.C., den. 2002. A catalogue of Actiniaria and Corallimorpharia from the Canary Islands and from Madeira // Arquipelago. Life and Marine Sciences. Vol.19A. P.33-54.

Riemann-Zürneck K. 1991. A new species of Sicyonis (Actiniaria: Actinostolidae) from the abyssal NE Atlantic // Mitteilungen aus dem Hamburgischen Zoologischen Museum und Institut. Vol.88. P.7-15.

Rodríguez E., López-González P.J. 2001. A new species of Hormathia (Actiniaria, Hormathiidae) from the easten Weddel Sea, Antactica // Helgoland Marine Research. Vol.55. P.116-123.

Rodríguez E., López-González P.J. 2013. New records of Antarctic and Sub-Antarctic sea anemones (Cnidaria, Anthozoa, Actiniaria and Corallimorpharia) from the Weddell Sea, Antarctic Peninsula, and Scotia Arc // Zootaxa. Vol.3624. No.1. P.1-100.

Sanamyan N., Sanamyan K., McDaniel N. 2013. Two new shallow water sea anemones of the family Actiniidae (Cnidaria: Anthozoa: Actiniaria) from British Colum- bia (NE Pacific) // Invertebrate Zoology. Vol.10. No.2. P.199-216.

Sanamyan N., Sanamyan K., Schories D. 2015. Shallow water Actiniaria and Corallimorpharia (Cnidaria: Anthozoa) from King George Island, Antarctica // Invertebrate Zoology. Vol.12. No.1. P.1-51.

Sanamyan N., Sanamyan K., Tabachnick K. 2012. The first species of Actiniaria, Spongiactis japonica gen.n., sp.n. (Cnidaria: Anthozoa) an obligate symbiont of a glass sponge // Invertebrate Zoology. Vol.9. No.2. P.127-141.

Schlining B., Jacobsen Stout, N. 2006. MBARI's video annotation and reference system // Proceedings of the Marine Technology Society/Institute of Electrical and Electronics Engineers Oceans Conference, Boston, MA. P.1-5.

Schmidt H. 1969. Die Nesselkapseln der Aktinien und ihre differentialdiagnostische Bedeutung // Helgoländer Wissenschaftliche Meeresuntersuchungen. Bd.19. S.284-317.

Schmidt H. 1972a. Die Nesselkapseln der Anthozoen und ihre Bedeutung für die phylogenetische Systematik // Helgoländer Wissenschaftliche Meeresuntersuchungen. Bd.23. S.422-458.

Schmidt H. 1972b. Prodromus zu einer Monographie der mediterranean Aktinien // Zoologica, Stuttgart. Bd.121. S.1-146.

Schmidt H. 1974. On evolution in the Anthozoa // Proceeding of the Second International Coral Reef Symposium 1. Great Barrier Reef Committee, Brisbane, October, 1974. P.533-560.

Stephenson T.A. 1918a. On certain Actiniaria collected off Ireland by the Irish Fisheries Department, during the years of 1899-1913 // Proceedings of the Royal Irish Academy. Vol.34B. No.7. P.106-164.

Stephenson T.A. 1918b. Coelenterata Pt.1 Actiniaria // Natural History Report of British Antarctic ('Terra Nova') Expedition, 1910. Zoology. Vol.5. No.1. P.168.

Weill R. 1934. Contribution a l'étude des Cnidaires et de leurs Nématocystes. Paris: Les Presses Universitaires de France. 701 p.

Williams G.C., Lundsten L. 2009. The nephtheid soft coral genus Gersemia (Marenzeller, 1878) with the description of a new species from the northeast Pacific and a review of two additional species (Octocorallia: Alcyonacea) // Zoologische Mededelingen Leiden. Vol.83. No.34. P.1067-1081.

Responsible editors: V.N. Ivanenko, M.J. Shreider 